\title{
Influence of treatment with and without extractions on the growth pattern of dolichofacial patients
}

\author{
Vanessa Scherer Porto', José Fernando Castanha Henriques², Guilherme Janson ${ }^{3}$, Marcos Roberto de Freitas ${ }^{4}$, Arnaldo Pinzan ${ }^{5}$
}

\begin{abstract}
Objective: The objective of this retrospective study was to compare, by means of lateral cephalograms, the facial growth pattern changes due to the treatment with and without extractions of four first premolars in dolichofacial individuals. Methods: Groups 1 and 2 were constituted of 23 dolichofacial patients each, with Class II malocclusion, division 1 and initial age average of 12.36 and 12.29 years, respectively. Patients from Group 1 were treated without extractions and Group 2 was treated with extraction of the four first premolars, given that both used occipital headgear. Groups were compatibilized according to age, treatment period, gender and malocclusion severity. The $t$ test was applied for intergroups comparison. Results: Most variables (SN.PP, SN.Ocl and FMA) did not present statistically significant difference between groups. Conclusion: Although the treatment with extractions tend to reduce the mandibular plane angle (SN.GoGn) and the facial axis (NS.Gn), the analyzed treatment protocols did not affect in a clinically relevant way the facial growth pattern.
\end{abstract}

Keywords: Angle Class II malocclusion. Vertical dimension. Tooth extraction.

Objetivo: o objetivo desse estudo retrospectivo foi comparar, por meio de telerradiografias, as alterações no padrão de crescimento facial decorrentes do tratamento sem e com extrações dos quatro primeiros pré-molares em indivíduos dolicofaciais. Métodos: os grupos 1 e 2 foram constituídos, cada um, por 23 pacientes dolicofaciais com má oclusão Classe II, divisão 1 e idade inicial média de 12,36 e 12,29 anos, respectivamente. Os pacientes do grupo 1 foram tratados sem extrações e os do grupo 2 foram tratados com extrações dos quatro primeiros pré-molares, sendo que ambos utilizaram aparelho extrabucal occipital. Os grupos foram compatibilizados de acordo com a idade, tempo de tratamento, sexo e severidade da má oclusão. $O$ teste $t$ foi aplicado para a comparação intergrupos. Resultados: a maioria das variáveis (SN. PP, SN.Ocl e FMA) não apresentou diferença estatisticamente significativa entre os grupos. Conclusão: apesar do tratamento com extrações tender a reduzir a inclinação do plano mandibular (SN.GoGn) e o eixo facial (NS.Gn), os protocolos de tratamento analisados não alteraram de forma clinicamente relevante o padrão de crescimento facial.

Palavras-chave: Má oclusão de Angle Classe II. Dimensão vertical. Extração dentária.

${ }^{1}$ MSc in Orthodontics, FOB-USP.

${ }^{2}$ Full Professor, Department of Orthodontics and Pediatric Dentistry and Public Health, FOB-USP.

${ }^{3}$ Full Professor of Orthodontics. Head of the Department of Pediatric Dentistry, Orthodontics and Public Health, FOB-USP.

${ }^{4}$ Full Professor of Orthodontics. Clinical Coordinator of Program of Orthodontics and Public Health, FOB-USP.

${ }^{5}$ Associated Professor of Orthodontics, FOB-USP.
How to cite this article: Porto VS, Henriques JFC, Janson G, de Freitas MR, Pinzan A. Influence of treatment with and without extractions on the growth pattern of dolichofacial patients. Dental Press J Orthod. 2012 Nov-Dec;17(6):69-75.

Submitted: January 21, 2009 - Revised and accepted: August 16, 2009

" The author reports no commercial, proprietary or financial interest in the products or companies described in this article.

Contact address: Vanessa Scherer Porto

Rua Becker Pinto, 106 - Dores - Santa Maria/RS - Brazil

CEP: 97.050-070 - E-mail: vanessascherer@hotmail.com 


\section{INTRODUCTION}

Long face is a deformity with skeletal involvement, an unfavorable esthetic prognosis.

Therefore, the orthodontic treatment high angle patients is challenging because the sought results are more difficult to be achieved. ${ }^{2}$ Orthodontic treatment can have favorable or unfavorable influences in the facial growth pattern. ${ }^{23}$ Downs ${ }^{10}$ documented favorable and unfavorable changes in facial axis of treated cases and reported that the effects of the treatment on growth can be better illustrated with a selection of extreme facial patterns, thus emphasized the importance of treatment considerations in relation to the growth pattern.

Ricketts $^{26}$ noticed that treatment with cervical headgear or Class II elastics had opening the facial axis an average of $1^{\circ}$ in different facial patterns. The great difference occurred in dolichofacial patients who were treated only with Class II elastics, where there was an increase of 2 to $5^{\circ}$ in the facial axis. He concluded that the appliance selection is effective in controlling the mentum behavior and recommended the use of the high-pull headgear to dolichofacials and cervical headgear to brachyfacials. Some authors recommend the use of occipital headgear to control the vertical dimension. ${ }^{3,12,14}$

The extraction of first premolars is generally recommended to decrease the lower anterior facial height with consequent mesialization of molars. ${ }^{11,19}$ According to Chua et al, ${ }^{5}$ the orthodontists generally believe that treatment without extractions is associated with backward rotation of the mandible and increase of the lower anterior facial height. Meanwhile, treatment with extractions is associated with mandibular counterclockwise rotation and diminished anterior facial height. However, most studies support the idea that extractions of premolars does not reduce the facial vertical dimension or change the growth pattern, because they advocated that all orthodontic treatment results in molar extrusion..$^{7,18,28,29}$ It is the facial growth pattern that determines the changes of the craniofacial structures after orthodontic treatment with extractions. ${ }^{29}$

Considering the necessity of vertical control during the orthodontic treatment in individuals with long facial pattern, the purpose of this investigation was to compare the facial growth changes due the treatment with and without four first premolars extractions in individuals dolichofacials with Class II malocclusion, division 1, treated with occipital headgear.

\section{MATERIAL AND METHODS}

The sample consisted of 92 lateral cephalograms of 46 Caucasian patients, taken before and after the completion of orthodontic treatment. The following selection criteria were used:

1) Young Brazilian Caucasians, with Mediterranean ancestry of Portuguese, Spaniards and/ or Italians.

2) Age from 10 to 15 years, of both genders.

3) Young people with vertical facial growth pattern (dolichofacials), with FMA angle greater than $28^{\circ}$.

4) Presence of Class II malocclusion, division 1 , being the severity of at least $1 / 2$ Class II of molar, established by means of medical records and study models.

5) Treated with or without extractions of four first premolars and with the simplified Edgewise arch technique associated with the occipital headgear.

6) Presence of all upper and lower permanent teeth (except second permanent molar) and without mutilations in dental arch.

7) Absence of any tooth anomaly.

The sample was divided into two groups:

» Group 1, composed of 46 cephalograms (23 pretreatment and 23 post treatment) of young people with vertical facial growth pattern (dolichofacials), Class II malocclusion, division 1. All patients were treated with fixed orthodontic appliance, occipital headgear and without extractions.

» Group 2, composed of 46 cephalograms (23 pretreatment and 23 post treatment) of young people with vertical facial growth pattern (dolichofacials), with Class II malocclusion, division 1. Patients were treated with fixed orthodontic appliance occipital headgear and four first premolars extraction.

To accomplish the orthodontic treatment, both groups were treated with Edgewise brackets, lip bumper (LB), intermaxillary elastics and an anchorage system consisted of a minimum of 14 hours of occipital headgear daily. 
After the delimitation of anatomical drawing and demarcation landmarks, the tracings were computerized using a Numonics A-30TLF digitizer by the same examiner and the data were stored and measured in the software Dentofacial Planner, version 7.02.

The following angular variables related to the growth pattern were assessed (Fig 1):

1. SN.PP - angle formed by SN line and the palatal plane.

2. SN.Ocl - angle formed by SN line and occlusal plane.

3. SN.GoGn - angle formed by SN line and the mandibular plane (GoGn).

4. FMA - angle formed by the Frankfort plane and the mandibular plane (GoMe).

5. NS. Gn - angle formed by the NS line and Gnation.

The orthodontic records of all patients were used to determine the facial growth pattern of groups 1 and 2. Those who had FMA angle greater than $28^{\circ}$ were selected. For the purposes of determining the malocclusion severity of patients selected for the sample of groups 1 and 2 the patients' orthodontic records and initial casts were assessed. The malocclusion was classified as Class I, 1/4 Class II, 1/2 Class II, $3 / 4$ Class II and complete Class II.

To belong to the sample, the patient should have at least $1 / 2$ Class II malocclusion in one side of the dental arches (right or left).

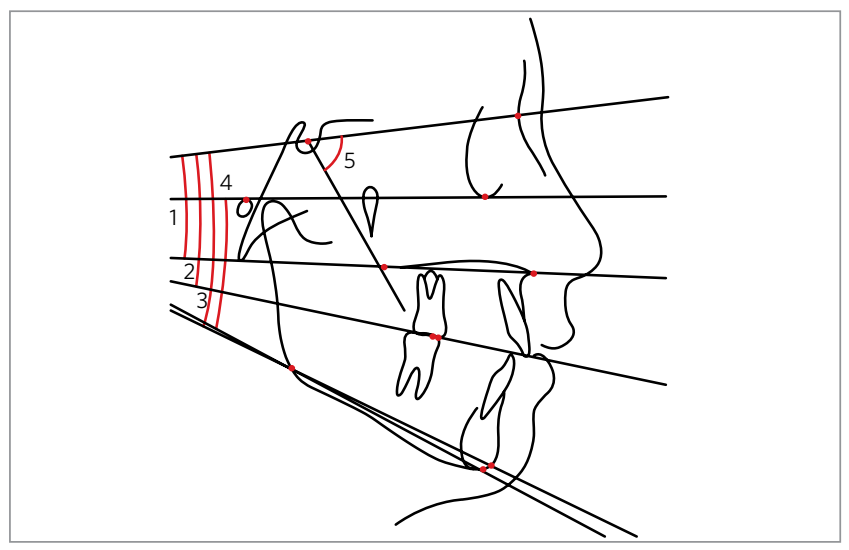

Figure 1 - Cephalometric tracing with the angular variables analyzed in the growth pattern. 1) SN.PP = angle formed by SN line and the palatal plane; 2$) \mathrm{SN} . \mathrm{Ocl}=$ angle formed by SN line and occlusal plane;

3) $S N . G o G n=$ angle formed by SN line and the mandibular plane (GoGn);

4) $F M A=$ angle formed by the Frankfort plane and the mandibular plane $(\mathrm{GoMe}) ; 5)$ NS.Gn = angle formed by the NS line and Gnation.

\section{Method error}

To determine the methodological error it were randomly selected 20 cephalograms. They were retraced and measured again, with an interval of one month between the measurements, obtaining two measures for the same variables, however, at different times. The difference between the first and second measurement of each variable was used to calculate the methodological errors. The systematic error was obtained with the application of paired $t$ test, the significance level of $5 \%$, comparing the means of each cephalometric magnitude of initial readings and repetitions of 20 randomly selected cephalograms. It was obtained the random error of values obtained at different times, according to the formula proposed by Dahlberg. ${ }^{8}$ It was considered that the errors over $1.5^{\circ}$ would be significant.

\section{Statistical analysis}

The homogeneity of the sample in relation to gender and severity of Class II malocclusion, division 1 was evaluated by the $\chi^{2}$ test. The $t$ test identified differences in the pre-treatment and changes during intergroups treatment. All tests were conducted using Statistica software and adopted a significance level of $5 \%$.

\section{RESULTS}

The method error, represented by systematic error and random error, did not provide statistically significant difference for any variable. Table 1 presents the initial and final mean ages of patients and evaluated treatment period, according to each group. There was no statistically significant difference on the initial and final ages of the individuals that comprise groups 1 and 2, as well as the treatment period. Table 2 shows through the $\chi^{2}$ test the balanced distribution of males and females in both groups. Table 3 shows a similar distribution of severity of Angle Class II, division 1, malocclusion, of patients selected to compose the sample through the $\chi^{2}$ sample.

The growth pattern in the pre-treatment (Table 4) was significantly more vertical in Group 2 than Group 1 only when FMA angle was assessed. Other variables such as SN.PP, SN.Ocl, SN.GoGn and NS.Gn did not show statistically significant differ- 
ence between groups 1 and 2 and indicated that both groups have a vector of craniofacial growth with vertical dominance.

Changes in the growth pattern in groups 1 and 2 are shown in Table 5. The growth pattern demonstrated a statistically significant difference between the groups in the mandibular angle (SN.GoGn) and facial axis (NS.Gn). Both variables decreased in Group 2 and increased in Group 1. Another difference between groups, but not statistically significant, occurred in relation to the FMA angle that decreased in Group 2 and increased in Group 1. The other variables, represented by the inclination of the palatal plan (SN.PP) and the occlusal plane (SN.Ocl), increased equally in both groups.

\section{DISCUSSION}

\section{Sample selection}

The selection of dolichofacials patients was done by assessing the FMA angle, as held in other studies. ${ }^{15,21}$ The mandibular plane angle with the Frankfort plane (FMA), according to Johnson, ${ }^{17}$ proved to be an important criterion for evaluation of the facial pattern. This angle is affected by the vertical development of the alveolar process, by the mandibular ramus growth and gonial angle. It were selected

Table 1 - Initial and final mean ages (years) of patients selected in the two groups and the treatment time.

\begin{tabular}{cccccc} 
& \multicolumn{3}{c}{ Group 1 (n= 23) } & & Group 2 (n= 23) \\
\cline { 2 - 6 } Variables (years) & Mean & SD & Mean & SD \\
Initial age & 12.36 & 1.14 & 12.29 & 1.03 \\
Final age & 14.55 & 1.25 & 14.78 & 0.81 \\
Treatment time & 2.18 & 0.45 & 2.48 & 0.51 & 0.69 \\
\hline
\end{tabular}

Table $2-\chi^{2}$ and balanced distribution of males and females in both groups.

\begin{tabular}{cccc} 
Group & Male gender & Female gender & Total \\
\hline 1 & 11 & 12 & 23 \\
2 & 9 & 14 & 23 \\
Total & 20 & 26 & 46 \\
& $\chi^{2}=0.35$ & $\mathrm{gl}=1$ & $\mathrm{p}=0.55$ \\
\hline
\end{tabular}

Table 4 - Differences between groups 1 and 2 during pre-treatment.

\begin{tabular}{cccccc} 
& \multicolumn{2}{c}{ Group 1 } & \multicolumn{2}{c}{ Group 2 } & \\
\cline { 2 - 4 } Variables & \multicolumn{2}{c}{ Pre-treatment } & \multicolumn{2}{c}{ Pre-treatment } & p \\
\cline { 2 - 4 } & Mean & SD & Mean & SD & \\
& \multicolumn{5}{c}{ Growth pattern } \\
SN.PP & 8.41 & 3.20 & 8.68 & 4.46 & 0.81 \\
SN.Ocl & 17.90 & 2.99 & 18.40 & 3.53 & 0.61 \\
SN.GoGn* & 38.03 & 3.06 & 39.99 & 3.64 & 0.05 \\
NS.Gn* & 70.50 & 2.22 & 71.91 & 3.79 & 0.13 \\
FMA $^{*}$ & 30.65 & 2.38 & 32.70 & 3.14 & 0.02 \\
\hline
\end{tabular}

*Statistical significative difference between groups.
Table 3 - $\chi^{2}$ and distribution of severity of Angle Class II, division 1, malocclusion, in both groups.

\begin{tabular}{|c|c|c|c|c|}
\hline Group & Class II 1/2 & Class II 3/4 & Class II complete & Total \\
\hline 1 & 12 & 4 & 7 & 23 \\
\hline 2 & 10 & 3 & 10 & 23 \\
\hline Total & 22 & 7 & 17 & 46 \\
\hline \multicolumn{2}{|c|}{$\chi^{2}=0.85$} & $g \mid=2$ & \multicolumn{2}{|l|}{$p=0.65$} \\
\hline
\end{tabular}

Table 5 - Changes occurred during treatment in both groups

\begin{tabular}{|c|c|c|c|c|c|}
\hline \multirow{3}{*}{ Variables } & \multirow{2}{*}{\multicolumn{2}{|c|}{$\begin{array}{l}\text { Group } 1 \\
\text { Changes }\end{array}$}} & \multirow{2}{*}{\multicolumn{2}{|c|}{$\begin{array}{l}\text { Group } 2 \\
\text { Changes }\end{array}$}} & \multirow{3}{*}{$\mathbf{p}$} \\
\hline & & & & & \\
\hline & Mean & SD & Mean & SD & \\
\hline \multicolumn{6}{|c|}{ Growth pattern } \\
\hline SN.PP & 0.22 & 2.38 & 0.01 & 2.67 & 0.78 \\
\hline SN.Od & 2.13 & 3.61 & 0.50 & 3.75 & 0.14 \\
\hline SN.GoGn* & 0.83 & 2.27 & -0.88 & 2.45 & 0.02 \\
\hline NS.Gn* & 1.15 & 1.64 & -0.51 & 2.03 & 0.00 \\
\hline FMA & 0.67 & 2.51 & -0.33 & 3.15 & 0.24 \\
\hline
\end{tabular}

*Statistical significative difference between groups. 
all patients who had in their medical records the angle FMA greater than $28^{\circ}$, because, according to Tweed, ${ }^{30}$ they have an unfavorable growth vector, i.e. greater vertical growth propensity. After the cephalograms were traced and digitalized, all those who had the FMA angle lower than $28^{\circ}$ were excluded from the sample.

It is known that the malocclusions associated with a vertical growth pattern or a relation between the anterior-posterior deficient bone bases provide a poor prognosis in orthodontic treatment. ${ }^{13}$ So, in order to evaluate individuals with complex prognosis in addition to the patients having vertical pattern of growth, it was selected those who had also a Class II division 1 malocclusion. With the goal of having a sample with the largest number of individuals, it was accepted Class II malocclusions of at least 1/2 molar relation subdivision.

Barton ${ }^{1}$ believed that cervical headgear tends to induce open bite and should be avoided in dolichofacials patients. However, Burke and Jacobson ${ }^{3}$ related that in individuals with long facial pattern and Class II malocclusion there was no significant difference in mandibular plane angle and facial height when were compared the groups treated with cervical and occipital headgear. However, the extrusion of molars and the increase in the occlusal plane angle were significantly higher in the group treated with cervical headgear. To better analyze the best results obtained in dolichofacials patients, only those individuals treated with occipital headgear were selected.

\section{Facial growth pattern}

In the present study, the changes in the palatal plane in relation to the base of the skull (SN.PP) were not significantly different between the groups treated with and without extractions. Instead, Kim et $\mathrm{al}^{18}$ reported statistically significant difference in the changes of SN.PP angle between groups treated with extractions of the first premolars than those treated with extractions of second premolars. The different methodology used in their study, as the non-use of headgear anchorage, may have influenced the different result reported by the authors.

The occlusal plane angle (SN.Ocl) had an increase in both groups treated with and without extractions, but this also failed to provide statistically significant difference. The same result was observed by Darendeliler and Taner-Sarizoy ${ }^{9}$ when evaluated the effects of treatment with extractions in patients with different growth patterns.

The mandibular plane angle (SN.GoGn) showed statistically significant difference between the groups. However, the $0.83^{\circ}$ increase in the SN.GoGn angle for the group without extractions and the $0.88^{\circ}$ reduction of the group with extractions probably do not characterize clinical significance. Studies carried out by Darendeliler and Taner-Sarizoy $^{9}$ and LaHaye et $\mathrm{al}^{20}$ did not report statistically significant difference of mandibular plane angle change during treatment. According to Cozza et al, ${ }^{6}$ the decrease in the SN.GoGn angle can be attributed mainly to the significant increase in height of the mandibular ramus. Hering et $\mathrm{al}^{16}$ noticed in their study that the mandibular plane angle did not increase with different types of treatment in patients with skeletal open bite. According to Cusimano et al, ${ }^{7}$ during treatment with extractions in dolichofacials patients, the mandibular plane remained parallel to the mandibular position of pre-treatment. According to Staggers, ${ }^{28}$ all orthodontic treatments increases the mandibular plane angle.

According to Ochoa and Nanda, ${ }^{25}$ the facial axis angle mean does not significantly change with age. They reported that male and female genders showed changes of less than $1^{\circ}$ between the ages of 6 to 20 years. However, according to Schudy, ${ }^{27}$ the facial axis increases on average from 8 to 15 years of age and it is influenced by vertical and horizontal growth. Moreover, the more the vertical growth surpasses the horizontal growth, the more the facial axis increases. In this research, changes in the facial axis (NS.Gn) presented statistically significant difference between groups. The group with extractions showed a decrease of angle while the group without the extractions increased the facial axis. This result differs from the study by Kapler et al, ${ }^{19}$ in which the axis had not demonstrated statistically significant facial difference between groups treated with and without extractions.

The FMA angle, in pre-treatment, was significantly different between the groups, presenting $32.70^{\circ}$ in the group with extractions and $30.65^{\circ}$ in the group 


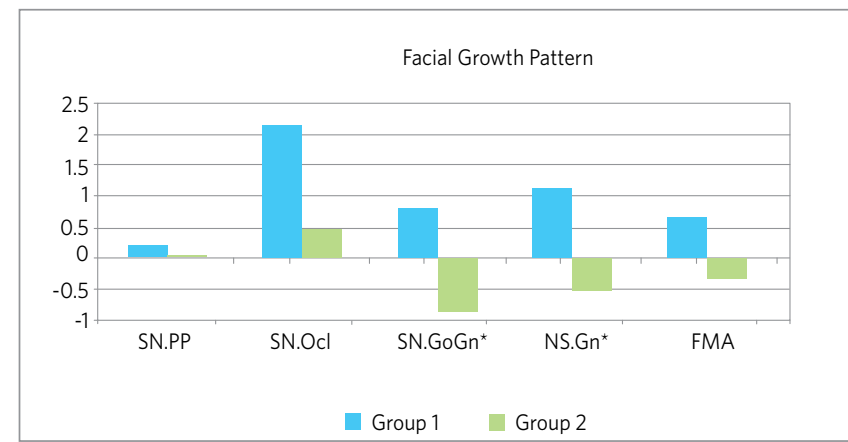

Figure 2 - Changes in the facial growth pattern of Groups 1 and 2 (* statistical significative difference between groups).

without extractions (Table 4). During treatment, the FMA angle increased in the group without extractions and decreased in the group with extractions. However, this difference between the groups was not statistically significant. With the purpose of investigating the skeletal and dental changes of Class II malocclusion treatment with occipital headgear, Firouz et $\mathrm{al}^{12}$ also did not observe statistically significant difference in the FMA angle between the control group and the group treated with the headgear without extractions. The same result was reported in the study of Lai et al. ${ }^{21}$

So, all variables related to the growth pattern in this research have increased in the group without extractions (Fig 2). However, in the group with extractions, there was a tendency of decreasing the angles related to growth pattern. Despite the changes in the mandibular plane angle (SN.GoGn) and the statistically significant difference in the facial axis (NS.Gn) between groups, $1.71^{\circ}$ and $1.66^{\circ}$, respectively, these differences probably do not characterize a clinical significance. Nanda et $\mathrm{al}^{24}$ observed in a longitudinal study of untreated patients, ages between 7 to 18 years, that the mandibular plane, occlusal plane, palatal plane and the gonial angle decrease with age. The same was reported by Haralabakis and Sifakakis, ${ }^{15}$ in which agreed that the treatment and especially the growth seem to favor the dolichofaciais. According to the authors, these progressive reductions of the angles improve or maintain the magnitude of vertical imbalance. They also reported that the vertical skeletal relation of face growing cannot be changed by means of extraoral force control. This study agrees with others that reported that treatment with premolar extractions does not significantly affect the growth pattern.,22,29

\section{CONCLUSION}

Despite that treatment with extractions tend to reduce the inclination of the mandibular plane angle (SN.GoGn) and the facial axis (NS.Gn), the analyzed treatment protocols did not clinically affect the pattern of facial growth. 


\section{REFERENCES}

1. Barton JJ. High-pull headgear versus cervical traction: a cephalometric comparison. Am J Orthod. 1972;62(5):517-29.

2. Bishara SE. Mandibular changes in persons with untreated and treated Class II division 1 malocclusion. Am J Orthod Dentofacial Orthop. 1998;113(6):661-73.

3. Burke M, Jacobson A. Vertical changes in high-angle Class II, division 1 patients treated with cervical or occipital pull headgear. Am J Orthod Dentofacial Orthop. 1992;102(6):501-8

4. Capelozza Filho L, Moura JA, Cavassan AO, Ozawa TO. Alterações verticais em casos de Classe II divisão 1 dentária com exodontias do quatro primeiros prémolares. Rev Dental Press Ortod Ortop Facial. 2000;5(5):12-9.

5. Chua AL, Lim JY, Lubit EC. The effects of extraction versus nonextraction orthodontic treatment on the growth of the lower anterior face height. Am J Orthod Dentofacial Orthop. 1993;104(4):361-8

6. Cozza P, Marino A, Franchi L. A nonsurgical approach to treatment of high-angle Class II malocclusion. Angle Orthod. 2008;78(3):553-60.

7. Cusimano C, McLaughlin RP, Zernik JH. Effects of first bicuspid extractions on facial height in high-angle cases. J Clin Orthod. 1993;27(11):594-8.

8. Dahlberg G. Statistical methods for medical and biological students. New York: Interscience; 1940.

9. Darendeliler N, Taner-Sarisoy L. The influence of orthodontic extraction treatment on dental structures: a two-factor evaluation. Eur J Orthod. 2001;23(3):295-303.

10. Downs WB. The role of cephalometrics in orthodontic case analysis and diagnosis. Am J Orthod. 1952;38(3):162-82.

11. Fields HW, Proffit WR, Nixon WL, Phillips C, Stanek E. Facial pattern differences in long-faced children and adults. Am J Orthod. 1984;85(3):217-23.

12. Firouz M, Zernik J, Nanda R. Dental and orthopedic effects of high-pull headgear in treatment of Class II, division 1 malocclusion. Am J Orthod Dentofacial Orthop. 1992;102(3):197-205.

13. Fogle LL, Southard KA, Southard TE, Casko JS. Treatment outcomes of growing Class II division 1 patients with varying degrees of anteroposterior and vertical dysplasias, Part 1. Cephalometrics. Am J Orthod Dentofacial Orthop. 2004;125(4):450-6.

14. Giancotti A. Nonextraction treatment of a high-angle Class II malocclusion: a case report. Am J Orthod Dentofacial Orthop. 2000;117(6):721-7.

15. Haralabakis NB, Sifakakis IB. The effect of cervical headgear on patients with high or low mandibular plane angles and the "myth" of posterior mandibular rotation. Am J Orthod Dentofacial Orthop. 2004;126(3):310-7.

16. Hering K, Ruf S, Pancherz H. Orthodontic treatment of openbite and deepbite highangle malocclusions. Angle Orthod. 1999;69(5):470-7.
17. Johnson EL. The Frankfort-mandibular plane angle and the facial pattern. Am J Orthod. 1950;36(7):516-33

18. Kim TK, Kim JT, Mah J, Yang WS, Baek SH. First or second premolar extraction effects on facial vertical dimension. Angle Orthod. 2005;75(2):177-82.

19. Klapper L, Navarro SF, Bowman D, Pawlowski B. The influence of extraction and nonextraction orthodontic treatment on brachyfacial and dolichofacial growth patterns. Am J Orthod Dentofacial Orthop. 1992;101(5):425-30.

20. LaHaye MB, Buschang PH, Alexander RG, Boley JC. Orthodontic treatment changes of chin position in Class II Division 1 patients. Am J Orthod Dentofacial Orthop. 2006;130(6):732-41.

21. Lai J, Ghosh J, Nanda RS. Effect of orthodontic therapy on the facial profile in long and short vertical facial patterns. Am J Orthod Dentofacial Orthop. 2000;118(5):505-13

22. Machado DT, Henriques JFC, Janson G, Freitas MR. Estudo cefalométrico das alterações das alturas faciais anterior e posterior em pacientes leucodermas, com má oclusão de Classe II, 1ำ divisão de Angle, tratados com e sem extração de quatro primeiros pré-molares. Rev Dental Press Ortod Ortop Facial. 2005;10(6):26-41.

23. Moore AW. Observations on facial growth and its significance. Am J Orthod Dentofacial Orthop. 1959;45(6):399-423.

24. Nanda RS, Meng H, Kapila S, Goorhuis J. Growth changes in the soft tissue facial profile. Angle Orthod. 1990;60(3):177-90.

25. Ochoa BK, Nanda RS. Comparison of maxillary and mandibular growth. Am J Orthod Dentofacial Orthop. 2004;125(2):148-59.

26. Ricketts RM. A study of changes in temporomandibular relations associated with treatment of Class II malocclusion. Am J Orthod. 1952;38(12):918-33.

27. Schudy FF. The Rotation of the mandible resulting from growth: its implications in orthodontic treatment. Angle Orthod. 1965;35:36-50.

28. Staggers JA. A comparison of results of second molar and first premolar extraction treatment. Am J Orthod Dentofacial Orthop. 1990;98(5):430-6

29. Taner-Sarisoy L, Darendeliler N. The influence of extraction orthodontic treatment on craniofacial structures: evaluation according to two different factors. Am J Orthod Dentofacial Orthop. 1999;115(5):508-14.

30. Tweed $\mathrm{CH}$. The Frankfort-mandibular plane angle in orthodontic diagnosis, classification, treatment planning, and prognosis. Am J Orthod Oral Surg. 1946;32(4):175-203. 